Review

\title{
Prevalence and Significance of Hypermetabolic Lymph Nodes Detected by 2-[18 F]FDG PET/CT after COVID-19 Vaccination: A Systematic Review and a Meta-Analysis
}

\author{
Giorgio Treglia ${ }^{1,2,3,4,5, * \mathbb{C}}$, Marco Cuzzocrea ${ }^{1}$, Luca Giovanella ${ }^{1,6} \mathbb{C}$, Luigia Elzi ${ }^{7,8,+}$ and Barbara Muoio ${ }^{7,+}$ \\ 1 Clinic of Nuclear Medicine, Imaging Institute of Southern Switzerland, Ente Ospedaliero Cantonale, \\ 6500 Bellinzona, Switzerland; marco.cuzzocrea@eoc.ch (M.C.); luca.giovanella@eoc.ch (L.G.) \\ 2 Department of Nuclear Medicine and Molecular Imaging, Lausanne University Hospital, \\ 1011 Lausanne, Switzerland \\ 3 Academic Education, Research and Innovation Area, General Directorate, Ente Ospedaliero Cantonale, \\ 6500 Bellinzona, Switzerland \\ 4 Faculty of Biology and Medicine, University of Lausanne, 1011 Lausanne, Switzerland \\ 5 Faculty of Biomedical Sciences, Università della Svizzera Italiana, 6900 Lugano, Switzerland \\ 6 Clinic for Nuclear Medicine, University Hospital and University of Zürich, 8091 Zürich, Switzerland \\ 7 Department of Medicine, Ente Ospedaliero Cantonale, 6500 Bellinzona, Switzerland; luigia.elzi@eoc.ch (L.E.); \\ barbara.muoio@eoc.ch (B.M.) \\ 8 Faculty of Medicine, University of Basel, 4056 Basel, Switzerland \\ * Correspondence: giorgio.treglia@eoc.ch; Tel.: +41-(91)-8118919 \\ † Luigia Elzi and Barbara Muoio share the last authorship.
}

Citation: Treglia, G.; Cuzzocrea, M.; Giovanella, L.; Elzi, L.; Muoio, B. Prevalence and Significance of Hypermetabolic Lymph Nodes Detected by 2-[ $\left.{ }^{18} \mathrm{~F}\right]$ FDG PET/CT after COVID-19 Vaccination: A Systematic Review and a Meta-Analysis. Pharmaceuticals 2021, 14, 762. https:// doi.org $/ 10.3390 /$ ph14080762

Academic Editors: Jean Jacques Vanden Eynde and Annie Mayence

Received: 12 July 2021

Accepted: 2 August 2021

Published: 3 August 2021

Publisher's Note: MDPI stays neutral with regard to jurisdictional claims in published maps and institutional affiliations.

Copyright: (c) 2021 by the authors. Licensee MDPI, Basel, Switzerland. This article is an open access article distributed under the terms and conditions of the Creative Commons Attribution (CC BY) license (https:// creativecommons.org/licenses/by/ $4.0 /)$.

\begin{abstract}
Recently, several articles reported incidental findings at 2-[ ${ }^{18}$ F]FDG PET/CT in patients who have received COVID-19 vaccinations, including hypermetabolic axillary lymph nodes (HALNs) ipsilateral to the COVID-19 vaccine injection site which may cause diagnostic dilemmas. The aim of our work was to calculate the prevalence of this finding. A comprehensive computer literature search of PubMed/MEDLINE, Embase, and Cochrane library databases was performed to identify recently published articles that investigated the prevalence of HALNs detected by $2-\left[{ }^{18} \mathrm{~F}\right]$ FDG PET /CT after COVID-19 vaccination. Pooled prevalence of this finding was calculated through a meta-analytic approach. Nine recently published articles including 2354 patients undergoing $2-\left[{ }^{18} \mathrm{~F}\right]$ FDG PET/CT after recent COVID-19 vaccination have been included in the systematic review. Overall, HALNs ipsilateral to the vaccine injection site were frequent findings mainly due to vaccine-related immune response in most of the cases. The pooled prevalence of HALNs after COVID-19 vaccination was 37\% (95\% confidence interval: $27-47 \%$ ) but with significant heterogeneity among the included studies. Physicians must be aware and recognize the significant frequency of HALNs at 2-[ ${ }^{18}$ F]FDG PET/CT related to immune response to vaccine injection. Larger studies are needed to confirm the findings of this systematic review and meta-analysis.
\end{abstract}

Keywords: COVID-19; vaccine; PET; FDG; lymph nodes; inflammation; systematic review; meta-analysis

\section{Introduction}

Since the beginning of 2020, several vaccines that can control the COVID-19 pandemic have been developed $[1,2]$. These vaccines, including messenger ribonucleic acid (mRNA), adenoviral-vectored, protein-subunit, and whole-cell inactivated-virus vaccines, have now reported efficacy in phase III trials, receiving approval in many countries [1,2]. Most COVID-19 vaccines are designed to elicit immune responses against the SARS-CoV-2 spike protein $[1,2]$.

Due to their immunological effects, vaccinations including those related to COVID-19 may cause various confusing imaging patterns that pose diagnostic challenges for clinicians and pitfalls for reading radiologists and nuclear medicine physicians [3-6]. On the other 
hand, some imaging methods could be of potential value to assess the immune response after vaccination, including those related to COVID-19 [3,4].

Fluorine-18 fluorodeoxyglucose $\left(2-\left[{ }^{18} \mathrm{~F}\right] \mathrm{FDG}\right)$ positron emission tomography / computed tomography is a hybrid imaging technique used for several indications including the evaluation of oncological and infectious/inflammatory diseases [7]. 2- $\left[{ }^{18} \mathrm{~F}\right] \mathrm{FDG}$ is a radiolabeled glucose analogue; this radiopharmaceutical is taken up by cells via cell membrane glucose transporters and subsequently phosphorylated with hexokinase inside most cells. The ability of $2-\left[{ }^{18}\right.$ F]FDG PET/CT to identify tumor lesions or sites of inflammation and infection is mainly related to the glycolytic activity of the neoplastic or inflammatory cells [7].

Incidental lesions detected by whole-body $2-\left[{ }^{18} \mathrm{~F}\right] \mathrm{FDG}$ PET/CT performed for several indications are widely described in the literature [8]. Since the COVID-19 vaccination programs began worldwide, several articles (mainly case reports) reported incidental findings at 2- $\left[{ }^{18} \mathrm{~F}\right]$ FDG PET/CT in patients who have received recent COVID-19 vaccinations $[5,6,9]$. These findings due to vaccine-related immune response are mainly represented by hypermetabolic axillary lymph nodes (HALNs) ipsilateral to the COVID-19 vaccine injection site (a case example is reported in Figure 1) and 2-[ $\left.{ }^{18} \mathrm{~F}\right] \mathrm{FDG}$ uptake in the vaccine injection site $[5,6,9]$.

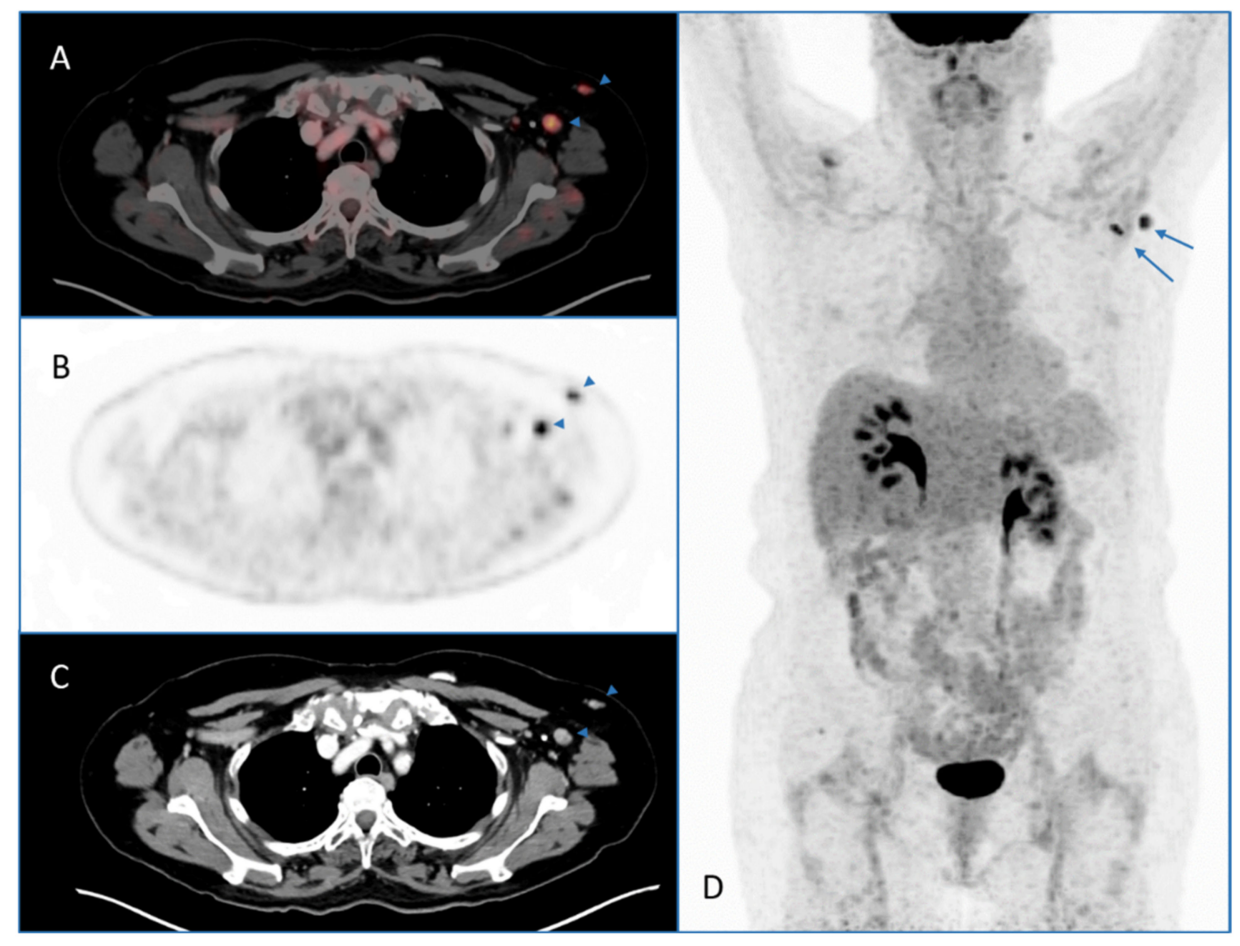

Figure 1. 2- $\left[{ }^{18} \mathrm{~F}\right] \mathrm{FDG}$ PET/CT performed for oncological indication in a patient with previous COVID-19 vaccination (3 weeks before 2- $\left[{ }^{18}\right.$ F]FDG PET/CT). Axial PET/CT (A), PET (B), and CT (C) images and maximum intensity projection (MIP) PET image (D) showed hypermetabolic axillary lymph nodes due to increased 2- $\left[{ }^{18} \mathrm{~F}\right]$ FDG uptake in the left axillary region (arrows). These findings were judged as reactive lymph nodes after COVID-19 vaccination.

As these incidental findings at 2-[18 F]FDG PET/CT may create several diagnostic dilemmas for radiologists and nuclear medicine physicians, in particular in discriminating between neoplastic and inflammatory lesions, the aim of this work was to perform a systematic review and meta-analysis of the existing literature to calculate their prevalence.

\section{Results}

\subsection{Literature Rearch}

A comprehensive computer literature search based on the review question and using PubMed/MEDLINE, Embase, and Cochrane library databases retrieved 70 records. Origi- 
nal articles reporting data about the prevalence of HALNs detected by $2-\left[{ }^{18} \mathrm{~F}\right] \mathrm{FDG}$ PET/CT after COVID-19 vaccination and including more than 10 patients were considered eligible for inclusion in this systematic review. Nine original articles were selected and retrieved in full-text version and 61 records were excluded. The detailed process of article selection is reported in Figure 2. There were no additional articles found after a further screening of the references of those selected articles. Thus, nine studies including 2354 patients were included in the qualitative and quantitative analyses [10-18]. The characteristics of the studies included in this systematic review are shown in Tables 1-3.

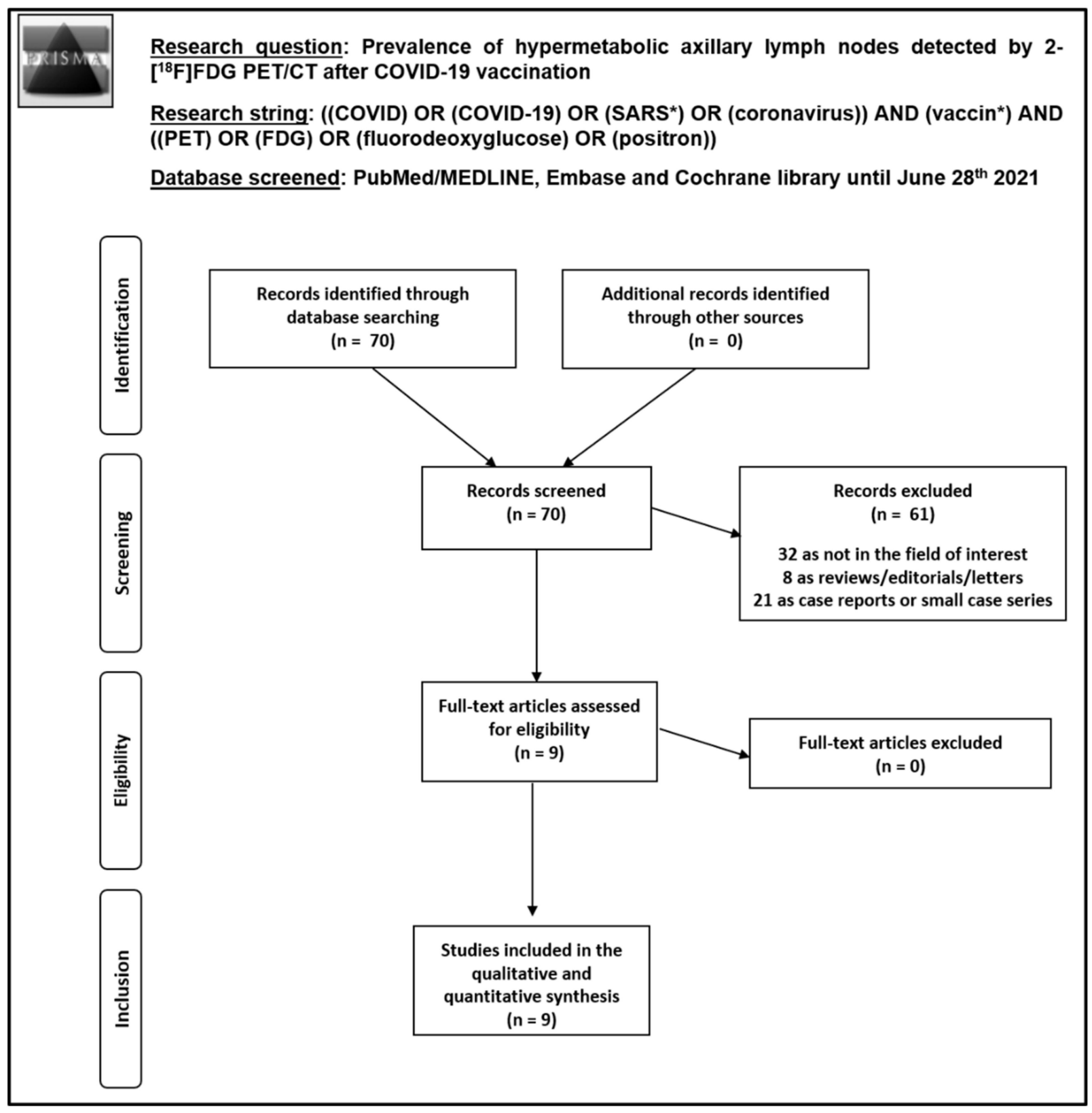

Figure 2. Process of article selection. 
Table 1. Basic study and patient characteristics.

\begin{tabular}{|c|c|c|c|c|c|c|c|c|c|c|}
\hline Authors & Country & Study Design & Type of Patients Evaluated & $\begin{array}{l}\text { No. of Patients } \\
\text { Evaluated with } \\
2-\text {-[18FTFDG }^{\text {PET/CT }}\end{array}$ & $\begin{array}{l}\text { Mean } \\
\text { Age }\end{array}$ & Male $\%$ & $\begin{array}{c}\text { Type of } \\
\text { COVID-19 } \\
\text { Vaccine } \\
\text { (Manufacturer) }\end{array}$ & $\begin{array}{c}\left.\text { 2-[18 }{ }^{18}\right] \text { FDG } \\
\text { PET/CT after First } \\
\text { Dose of } \\
\text { COVID-19 } \\
\text { Vaccine }\end{array}$ & $\begin{array}{c}\text { 2-[18 F]FDG } \\
\text { PET/CT after } \\
\text { Second Dose of } \\
\text { COVID-19 } \\
\text { Vaccine }\end{array}$ & $\begin{array}{c}\text { Time between } \\
\text { COVID-19 } \\
\text { Vaccination and } \\
\text { PET/CT Scan } \\
\text { (Days) }\end{array}$ \\
\hline Adin et al. [10] & USA & $\mathrm{R}$ & $\begin{array}{l}\text { Patients with previous recent COVID-19 vaccination } \\
\text { who underwent } 2-{ }^{18} \mathrm{~F} \text { FIFDG PET } / C T \text { for oncological or } \\
\text { other indications }\end{array}$ & 68 & 75 & $47 \%$ & $\begin{array}{l}\text { mRNA vaccine } \\
\text { (Moderna and } \\
\text { Pfizer) }\end{array}$ & $41(60 \%)$ & $27(40 \%)$ & $1-47$ \\
\hline Bernstine et al. [11] & Israel & $\mathrm{R}$ & $\begin{array}{c}\text { Patients with previous recent COVID-19 vaccination } \\
\text { who underwent } 2-\left[^{18} \text { F]FDG PET/CT for oncological }\right. \\
\text { indications }\end{array}$ & 650 & 69 & $46 \%$ & $\underset{\text { (Pfizer) }}{\text { mRNA vaccine }}$ & $394(61 \%)$ & $256(39 \%)$ & NR \\
\hline Cohen et al. [12] & Israel & $\mathrm{R}$ & $\begin{array}{c}\text { Patients with previous recent COVID-19 vaccination } \\
\left.\text { who underwent } 2-{ }^{18} \mathrm{~F}\right] \mathrm{FDG} \text { PET/CT for oncological or } \\
\text { other indications }\end{array}$ & 728 & 69 & $43 \%$ & $\begin{array}{c}\text { mRNA vaccine } \\
\text { (Pfizer) }\end{array}$ & $346(48 \%)$ & $382(52 \%)$ & NR \\
\hline Cohen et al. [13] & Israel & $\mathrm{R}$ & $\begin{array}{l}\text { Patients with previous recent COVID-19 vaccination } \\
\left.\text { who underwent } 2-{ }^{18} \mathrm{~F}\right] \mathrm{FDG} \text { PET/CT for evaluation of } \\
\text { hematological malignancy }\end{array}$ & 137 & 68.5 & $55 \%$ & $\begin{array}{l}\text { mRNA vaccine } \\
\text { (Pfizer) }\end{array}$ & $51(37 \%)$ & $86(63 \%)$ & $5-30$ \\
\hline Eifer et al. [14] & Israel & $\mathrm{R}$ & $\begin{array}{l}\text { Patients with previous recent COVID-19 vaccination } \\
\text { who underwent PET/CT with several radiotracers for } \\
\text { oncological or other indications }\end{array}$ & 377 & 67 & $51 \%$ & $\begin{array}{l}\text { mRNA vaccine } \\
\text { (Pfizer) }\end{array}$ & $301(80 \%)$ & $76(20 \%)$ & $1-34$ \\
\hline Eshet et al. [15] & Israel & $\mathrm{R}$ & $\begin{array}{l}\text { Patients with previous COVID-19 vaccination who } \\
\left.\text { underwent } 2-{ }^{18} \mathrm{~F}\right] \mathrm{FDG} \text { PET } / \mathrm{CT} \text { for oncological or other } \\
\text { indication beyond } 6 \text { weeks after vaccination }\end{array}$ & 169 & 65 & $51 \%$ & $\underset{\text { (Pfizer) }}{\operatorname{mRNA} \text { vaccine }}$ & 0 & $169(100 \%)$ & $42-71$ \\
\hline Schroeder et al. [16] & USA & $\mathrm{R}$ & $\begin{array}{c}\text { Patients with previous recent COVID-19 vaccination } \\
\text { who underwent } 2-{ }^{18} \text { FjFDG or radiolabeled choline } \\
\text { PET/CT for oncological indications }\end{array}$ & 54 & 76 & $64 \%$ & $\begin{array}{l}\text { mRNA vaccine } \\
\text { (Moderna and } \\
\text { Pfizer) }\end{array}$ & NR & NR & $1-42$ \\
\hline Shin et al. [17] & Korea & $\mathrm{R}$ & $\begin{array}{l}\text { Healthy subjects with previous recent COVID-19 } \\
\text { vaccination who underwent } 2-\left[^{18} \text { FJFDG PET/CT for }\right. \\
\text { cancer screening }\end{array}$ & 31 & 45 & $35 \%$ & $\begin{array}{l}\text { Adenovirus- } \\
\text { vectored } \\
\text { vaccine } \\
\text { (AstraZeneca) }\end{array}$ & NR & NR & $1-29$ \\
\hline Skawran et al. [18] & Switzerland & $\mathrm{R}$ & $\begin{array}{c}\text { Patients with previous recent COVID-19 vaccination } \\
\text { who underwent } 2-\left[{ }^{18} \mathrm{~F}\right] \mathrm{FDG} \text { PET } / \mathrm{CT} \text { for oncological } \\
\text { indications }\end{array}$ & 140 & 67 & $72 \%$ & $\begin{array}{l}\text { mRNA vaccine } \\
\text { (Moderna and } \\
\text { Pfizer) }\end{array}$ & $48(34 \%)$ & $92(66 \%)$ & $0-48$ \\
\hline
\end{tabular}

Legend: $2-\left[{ }^{18} \mathrm{~F}\right] \mathrm{FDG}$ = fluorine-18 fluorodeoxyglucose; $\mathrm{mRNA}=$ messenger ribonucleic acid; $\mathrm{NR}=$ not reported; $\mathrm{PET} / \mathrm{CT}=$ positron emission tomography $/$ computed tomography; $\mathrm{R}=$ retrospective. 
Table 2. Technical aspects of 2-[ $\left.{ }^{18} \mathrm{~F}\right] \mathrm{FDG}$ PET/CT in the included studies.

\begin{tabular}{|c|c|c|c|c|c|}
\hline Authors & $\begin{array}{l}\text { Hybrid Imaging Modality } \\
\text { and PET/CT Scanner }\end{array}$ & $\begin{array}{c}\text { Fasting before } \\
\text { 2-[18} \text { F]FDG Injection }\end{array}$ & $\begin{array}{c}\text { Mean Injected 2-[18} \text { F]FDG } \\
\text { Activity }\end{array}$ & $\begin{array}{l}\text { Time Interval between } \\
\text { 2-[18} \text { F]FDG Injection } \\
\text { and Image Acquisition }\end{array}$ & Image Analysis \\
\hline Adin et al. [10] & NR & $4-6 h$ & NR & $1 \mathrm{~h}$ & Visual \\
\hline Bernstine et al. [11] & $\begin{array}{l}\text { PET/CT (contrast enhanced } \\
\text { CT) using GE Discovery } 710 \\
\text { PET/CT (contrast enhanced }\end{array}$ & NR & $185-370 \mathrm{MBq}$ & NR & Visual and semi-quantitative $\left(\mathrm{SUV}_{\max }\right)$ \\
\hline Cohen et al. [12] & $\begin{array}{l}\text { CT) using GE Discovery } 690 \\
\text { or GE Discovery MI } \\
\text { PET/CT (contrast enhanced }\end{array}$ & NR & $3.7 \mathrm{MBq} / \mathrm{kg}$ & $1 \mathrm{~h}$ & Visual and semi-quantitative $\left(\mathrm{SUV}_{\max }\right)$ \\
\hline Cohen et al. [13] & $\begin{array}{l}\text { CT) using GE Discovery } 690 \\
\text { or GE Discovery MI }\end{array}$ & NR & $3.7 \mathrm{MBq} / \mathrm{kg}$ & $1 \mathrm{~h}$ & Visual and semi-quantitative $\left(\mathrm{SUV}_{\max }\right)$ \\
\hline Eifer et al. [14] & $\begin{array}{l}\text { PET/CT (low dose CT) using } \\
\text { Philips Vereos }\end{array}$ & $2-6 \mathrm{~h}$ & $5.18 \mathrm{MBq} / \mathrm{kg}$ & $1 \mathrm{~h}$ & Visual and semi-quantitative $\left(\mathrm{SUV}_{\max }\right)$ \\
\hline Eshet et al. [15] & $\begin{array}{l}\text { PET/CT (low dose CT) using } \\
\text { Philips Vereos }\end{array}$ & NR & NR & NR & Visual and semi-quantitative $\left(\mathrm{SUV}_{\max }\right)$ \\
\hline Schroeder et al. [16] & $\begin{array}{l}\text { PET/CT (low dose CT) using } \\
\text { GE Discovery 690, GE } \\
\text { Discovery 710, GE Discovery } \\
\text { MI or Siemens Biograph } \\
\text { Vision } 600\end{array}$ & $11 \mathrm{~h}$ & $437 \mathrm{MBq}$ & $1 \mathrm{~h}$ & Visual and semi-quantitative $\left(\mathrm{SUV}_{\max }\right)$ \\
\hline Shin et al. [17] & $\begin{array}{l}\text { PET/CT (low dose CT) using } \\
\text { GE Discovery STE }\end{array}$ & At least $6 \mathrm{~h}$ & $5 \mathrm{MBq} / \mathrm{kg}$ & $1 \mathrm{~h}$ & Visual and semi-quantitative $\left(\mathrm{SUV}_{\max }\right)$ \\
\hline Skawran et al. [18] & $\begin{array}{l}\text { PET/CT (low dose CT) using } \\
\text { GE Discovery MI }\end{array}$ & At least $4 \mathrm{~h}$ & $1.5-3.1 \mathrm{MBq} / \mathrm{kg}$ & $1 \mathrm{~h}$ & Visual and semi-quantitative $\left(\mathrm{SUV}_{\max }\right)$ \\
\hline
\end{tabular}

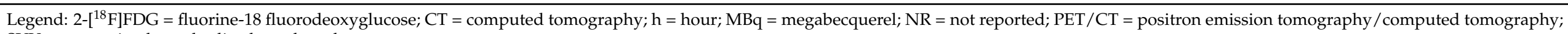
$\mathrm{SUV}_{\text {max }}=$ maximal standardized uptake value. 
Table 3. Data on the prevalence of hypermetabolic axillary lymph nodes and deltoid muscle uptake at 2-[ ${ }^{18}$ F]FDG PET/CT after COVID-19 vaccine.

\begin{tabular}{|c|c|c|c|c|c|c|c|}
\hline \multirow{2}{*}{ Authors } & \multicolumn{3}{|c|}{$\begin{array}{l}\text { All Cases Evaluated with } 2-\left[{ }^{18} \text { F]FDG PET/CT after COVID-19 }\right. \\
\text { Vaccine }\end{array}$} & \multicolumn{2}{|c|}{$\begin{array}{l}\text { Cases Evaluated with } 2-\left[{ }^{18} \text { F]FDG PET/CT }\right. \\
\text { after the First Dose of COVID-19 Vaccine }\end{array}$} & \multicolumn{2}{|c|}{$\begin{array}{l}\text { Cases Evaluated with 2-[18 F]FDG PET/CT } \\
\text { after the Second Dose of COVID-19 Vaccine }\end{array}$} \\
\hline & HALNs Present & HALNs Absent & $\begin{array}{l}\text { Uptake at Injection Site } \\
\text { of COVID-19 Vaccine }\end{array}$ & HALNs Present & HALNs Absent & HALNs Present & HALNs Absent \\
\hline Adin et al. [10] & $\begin{array}{l}9 / 68 \\
(13 \%)\end{array}$ & $\begin{array}{l}59 / 68 \\
(87 \%)\end{array}$ & $\begin{array}{l}8 / 68 \\
(12 \%)\end{array}$ & $\begin{array}{l}2 / 41 \\
(5 \%)\end{array}$ & $\begin{array}{l}39 / 41 \\
(95 \%)\end{array}$ & $\begin{array}{l}7 / 27 \\
(26 \%)\end{array}$ & $\begin{array}{l}20 / 27 \\
(74 \%)\end{array}$ \\
\hline Bernstine et al. [11] & $\begin{array}{c}168 / 650 \\
(26 \%)\end{array}$ & $\begin{array}{l}482 / 650 \\
(74 \%)\end{array}$ & $\begin{array}{l}52 / 168 \\
(31 \%)\end{array}$ & $\begin{array}{c}57 / 394 \\
(14 \%)\end{array}$ & $\begin{array}{c}337 / 394 \\
(86 \%)\end{array}$ & $\begin{array}{c}111 / 256 \\
(43 \%)\end{array}$ & $\begin{array}{c}145 / 256 \\
(57 \%)\end{array}$ \\
\hline Cohen et al. [13] & $\begin{array}{c}43 / 137 \\
(31 \%)\end{array}$ & $\begin{array}{c}94 / 137 \\
(69 \%)\end{array}$ & NA & $\begin{array}{l}13 / 51 \\
(25 \%)\end{array}$ & $\begin{array}{l}38 / 51 \\
(75 \%)\end{array}$ & $\begin{array}{l}30 / 86 \\
(35 \%)\end{array}$ & $\begin{array}{l}56 / 86 \\
(65 \%)\end{array}$ \\
\hline Eifer et al. [14] & $\begin{array}{c}170 / 377 \\
(45 \%)\end{array}$ & $\begin{array}{c}207 / 377 \\
(55 \%)\end{array}$ & $\begin{array}{l}98 / 377 \\
(26 \%)\end{array}$ & NA & NA & NA & NA \\
\hline Eshet et al. [15] & $\begin{array}{c}49 / 169 \\
(29 \%)\end{array}$ & $\begin{array}{c}120 / 169 \\
(71 \%)\end{array}$ & NA & NA & NA & $\begin{array}{c}49 / 169 \\
(29 \%)\end{array}$ & $\begin{array}{c}120 / 169 \\
(71 \%)\end{array}$ \\
\hline Shin et al. [17] & $\begin{array}{l}28 / 31 \\
(90 \%)\end{array}$ & $\begin{array}{c}3 / 31 \\
(10 \%)\end{array}$ & $\begin{array}{l}22 / 30 \\
(73 \%)\end{array}$ & NA & NA & NA & NA \\
\hline Skawran et al. [18] & $\begin{array}{c}75 / 140 \\
(54 \%)\end{array}$ & $\begin{array}{c}65 / 140 \\
(46 \%)\end{array}$ & NA & $\begin{array}{l}27 / 48 \\
(56 \%)\end{array}$ & $\begin{array}{l}21 / 48 \\
(44 \%)\end{array}$ & $\begin{array}{l}48 / 92 \\
(52 \%)\end{array}$ & $\begin{array}{l}44 / 92 \\
(48 \%)\end{array}$ \\
\hline $\begin{array}{l}\text { Pooled values } \\
\quad(95 \% \mathrm{CI})\end{array}$ & $\begin{array}{c}37 \% \\
(27-47 \%)\end{array}$ & $\begin{array}{c}63 \% \\
(53-73 \%)\end{array}$ & $\begin{array}{c}30 \% \\
(20-41 \%)\end{array}$ & $\begin{array}{c}26 \% \\
(13-42 \%)\end{array}$ & $\begin{array}{c}74 \% \\
(58-87 \%)\end{array}$ & $\begin{array}{c}41 \% \\
(32-50 \%)\end{array}$ & $\begin{array}{c}59 \% \\
(50-68 \%)\end{array}$ \\
\hline Heterogeneity $\left(\mathrm{I}^{2}\right)$ & High (95\%) & High (95\%) & High $(90 \%)$ & High (95\%) & High (95\%) & High $(87 \%)$ & High $(87 \%)$ \\
\hline $\begin{array}{c}\text { Egger's test } \\
\text { (publication bias) }\end{array}$ & $p=0.8$ (absent) & $p=0.8$ (absent) & $p=0.6$ (absent) & $p=0.5$ (absent) & $p=0.5$ (absent) & $p=0.3$ (absent) & $p=0.3$ (absent) \\
\hline
\end{tabular}

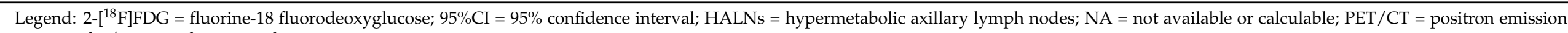
tomography/computed tomography. 


\subsection{Qualitative Synthesis (Systematic Review)}

Nine recently published articles including 2354 patients undergoing $2-\left[{ }^{18} \mathrm{~F}\right] \mathrm{FDG}$ PET/CT after recent COVID-19 vaccination were included in the systematic review [10-18]. Patient and basic studies characteristic are reported in Table 1.

All the articles were retrospective monocentric studies with mild quality according with the NIH National Heart, Lung, and Blood Institute Study Quality Assessment Tools. Five out of nine studies were carried out in Israel, two in USA, one in Korea and one in Switzerland.

With respect to patient characteristics, most of the patients included in the selected articles underwent 2-[ $\left.{ }^{18} \mathrm{~F}\right] \mathrm{FDG}$ PET/CT for oncological indications. Mean age largely varied among the studies, from 45 to 76 years. The male sex ratio also varied among the included studies between $35 \%$ and $72 \%$.

With respect to the type of COVID-19 vaccination, mRNA vaccination was performed in eight out nine studies whereas adenovirus vectored vaccine was carried out in one study only. The time between COVID-19 vaccination and 2-[ $\left[{ }^{18} \mathrm{~F}\right]$ FDG PET/CT largely varied among the studies from one to 71 days. Furthermore, in cases of COVID-19 vaccines administered in two doses, some patients underwent $2-\left[{ }^{18} \mathrm{~F}\right] \mathrm{FDG}$ PET /CT after the first dose (from $34 \%$ to $80 \%$ of cases) and others after the second dose (from $20 \%$ to $100 \%$ of cases).

As shown in Table 2, technical aspects of $2-\left[{ }^{18} \mathrm{~F}\right] \mathrm{FDG}$ PET/CT largely varied among the included studies.

Overall, all the studies reported that HALNs ipsilateral to the vaccine injection site were present in a significant percentage of patients undergoing 2- $\left[{ }^{18} \mathrm{~F}\right] \mathrm{FDG}$ PET/CT after COVID-19 vaccination (Table 3 ) and they were considered as a consequence of vaccinerelated immune response in most of the cases. The percentage of HALNs detected by 2- $\left[{ }^{18}\right.$ F]FDG PET /CT after COVID-19 vaccine ranged from 7\% to $90 \%$ of cases; $2-\left[{ }^{18}\right.$ F]FDG uptake at the vaccine injection site was also frequently reported (from $12 \%$ to $70 \%$ of cases). In most of the studies, an increase of percentage of HALNs detected by $2-\left[{ }^{18} \mathrm{~F}\right] \mathrm{FDG}$ PET/CT after the second dose of vaccine compared to the first dose was reported. Even if there was not difference in number, size, or $2-\left[{ }^{18} \mathrm{~F}\right] \mathrm{FDG}$ uptake of HALNs among the two groups, after the booster vaccine the incidence of high-intensity HALN was higher than after the first vaccine, and so was the size of nodes, detection of hypermetabolic lymph nodes beyond the ipsilateral axillary region (e.g., supraclavicular and cervical lymph nodes), and detection of the vaccination site.

Most of HALNs detected by 2-[18 F]FDG PET/CT were not enlarged at CT scan ( $<10 \mathrm{~mm}$ short axis). HALNs were more frequent in immunocompetent than in immunocompromised patients; furthermore, these findings were more frequent and with higher $2-\left[{ }^{18} \mathrm{~F}\right]$ FDG uptake in younger than in older patients ( $>64$ years old).

With respect to the time points, the incidence and grade of HALNs were highest during the first weeks after COVID-19 vaccine and decreased gradually over time. A significant percentage of these findings was even observed more than six weeks after vaccination with persistence even at 10 weeks after COVID-19 vaccination.

In patients with hematological malignancy, HALNs detected on $2-\left[{ }^{18} \mathrm{~F}\right] \mathrm{FDG}$ PET/CT positively correlated with antibody-mediated immune response to COVID-19 vaccine.

In those studies comparing different COVID-19 vaccinations, HALNs at 2- $\left[{ }^{18} \mathrm{~F}\right] \mathrm{FDG}$ PET/CT were more frequent after Moderna than after Pfizer vaccine.

Even if HALNs ipsilateral to the vaccine injection site were considered as vaccinerelated reactive lymph nodes in most of the cases, the nature of the HALNs may have been equivocal in a minority of cases and malignancy cannot be excluded on PET/CT image analysis only (i.e., women with breast cancer ipsilateral to the vaccination arm, lymphoma patients with nodal disease above the diaphragm, and patients with upper limb sarcoma, melanoma, or head and neck malignancy with extensive nodal involvement). Additional 
focused sonography of the region and fine-needle aspiration were suggested as useful in these cases to exclude malignancy.

\subsection{Quantitative Synthesis (Meta-Analysis)}

Results of the quantitative analysis are reported in Table 3. The pooled prevalence of HALNs ipsilateral to vaccine injection site and detected by $2-\left[{ }^{18} \mathrm{~F}\right] \mathrm{FDG}$ PET/CT after recent COVID-19 vaccination was $37 \%$ with $95 \%$ confidence interval values $(95 \% \mathrm{CI})$ ranging from $27 \%$ to $47 \%$. Pooled prevalence of 2-[ ${ }^{18}$ F]FDG uptake in the injection site after COVID-19 vaccination was 30\% (95\%CI: $20-41 \%)$. A significant heterogeneity across studies was found by the $\mathrm{I}^{2}$ index whereas a significant publication bias was excluded by the Egger's test.

Subgroup analyses taking into account first and second dose of COVID-19 vaccine demonstrated a higher prevalence of HALN after the second dose compared to the first dose ( $41 \%$ vs. $26 \%$ ) even if this difference was not statistically significant due to the partial overlap of $95 \%$ CI values among these groups. Unfortunately, due to the limited number of available articles, other subgroup analyses to statistically explore the heterogeneity could not be performed (i.e., considering different types of COVID-19 vaccine or different time points after COVID-19 vaccination).

\section{Discussion}

During the SARS-CoV-2 pandemic several 2-[ $\left.{ }^{18} \mathrm{~F}\right] \mathrm{FDG}$ PET/CT imaging findings associated with COVID-19 were described [19-21]. Further 2-[ ${ }^{18}$ F]FDG PET/CT findings were described after the introduction of COVID-19 vaccines [5,6,9], in particular HALNs ipsilateral to the vaccine injection site. Our systematic review and meta-analysis clearly demonstrates that this 2-[18 F]FDG PET/CT finding is frequent after recent COVID-19 vaccination and it is due to immune response to the vaccine in most of the cases [10-18]. Recognition of the vaccine-related HALNs may avoid patient anxiety and unnecessary further examinations or biopsies. These results seem to be in line with those of previous studies reporting a significant prevalence of HALNs after recent vaccinations beyond those related to COVID-19 (Table 4) [22-29].

Table 4. Data on the prevalence of hypermetabolic lymph nodes at 2-[18 F]FDG PET/CT after injection of other vaccines beyond COVID-19.

\begin{tabular}{|c|c|c|c|c|c|}
\hline \multirow[b]{2}{*}{ Authors and Year } & \multirow{2}{*}{$\begin{array}{c}\text { Target of } \\
\text { Vaccination }\end{array}$} & \multirow{2}{*}{$\begin{array}{l}\text { Time Interval from Vaccine } \\
\text { Injection to } 2-\left[{ }^{18} \text { F]FDG }\right. \\
\text { PET/CT Scan (Days) }\end{array}$} & \multicolumn{3}{|c|}{ Cases Evaluated with $2-\left[{ }^{18}\right.$ F]FDG PET/CT after Vaccination } \\
\hline & & & $\begin{array}{l}\text { HyperMetabolic } \\
\text { LN Present }\end{array}$ & $\begin{array}{l}\text { HyperMetabolic } \\
\text { LN Present }\end{array}$ & $\begin{array}{l}\text { Uptake at Injection } \\
\text { Site of Vaccine }\end{array}$ \\
\hline Burger et al. 2011 [22] & Influenza & $1-30$ & $\begin{array}{l}17 / 58 \\
(29 \%)\end{array}$ & $\begin{array}{l}41 / 58 \\
(71 \%)\end{array}$ & $\begin{array}{l}17 / 58 \\
(29 \%)\end{array}$ \\
\hline Coates et al. 2017 [23] & Papillomavirus & $8-37$ & $\begin{array}{c}15 / 15 \\
(100 \%)\end{array}$ & $\begin{array}{l}0 / 15 \\
(0 \%)\end{array}$ & NA \\
\hline Iyenga et al. 2003 [24] & Influenza & $3-5$ & $\begin{array}{c}7 / 8 \\
(87 \%)\end{array}$ & $\begin{array}{c}1 / 8 \\
(13 \%)\end{array}$ & NA \\
\hline Nakata et al. 2021 [25] & Anti-cancer & $1-1159$ & NA & NA & $\begin{array}{l}33 / 37 \\
(89 \%)\end{array}$ \\
\hline Panagiotidis et al. 2010 [26] & Influenza & $2-18$ & $\begin{array}{c}10 / 10 \\
(100 \%)\end{array}$ & $\begin{array}{l}0 / 10 \\
(0 \%)\end{array}$ & NA \\
\hline Shirone et al. 2012 [27] & Influenza & $<7$ or $\geq 7$ & $\begin{array}{l}4 / 83 \\
(5 \%)\end{array}$ & $\begin{array}{l}79 / 83 \\
(95 \%)\end{array}$ & NA \\
\hline Thomassen et al. 2011 [28] & Influenza & $1-330$ & NA & NA & NA \\
\hline Win et al. 2021 [29] & $\begin{array}{l}\text { Several types of } \\
\text { viruses }\end{array}$ & $1-10$ & $\begin{array}{l}38 / 53 \\
(72 \%)\end{array}$ & $\begin{array}{l}15 / 53 \\
(28 \%)\end{array}$ & NA \\
\hline
\end{tabular}

Legend: $2-\left[{ }^{18} \mathrm{~F}\right] \mathrm{FDG}=$ fluorine-18 fluorodeoxyglucose; $95 \% \mathrm{CI}=95 \%$ confidence interval; $\mathrm{LN}=1 \mathrm{mmph}$ nodes; $\mathrm{NA}=$ not available or calculable; PET/CT = positron emission tomography/computed tomography.

The high frequency of HALNs at 2-[ ${ }^{18}$ F]FDG PET/CT after recent COVID-19 vaccination could be explained by the high sensitivity of this imaging method for detection of inflammatory abnormalities and immune response including reactive lymph nodes; cells 
involved in inflammation and immune response are able to take up 2- $\left[{ }^{18} \mathrm{~F}\right] \mathrm{FDG}$ due to their expression of high levels of glucose transporters and high hexokinase activity [7].

HALNs at 2- $\left[{ }^{18}\right.$ F]FDG PET /CT after recent COVID-19 vaccination were not enlarged in the majority of cases. This is not surprising as functional/metabolic abnormalities detected by $2-\left[{ }^{18} \mathrm{~F}\right]$ FDG PET usually precede morphological abnormalities detected by CT scan and other conventional imaging methods [7]. Furthermore, the pooled prevalence of HALNs detected by 2- $\left[{ }^{18} \mathrm{~F}\right]$ FDG PET/CT was higher than the prevalence of axillary lymphadenopathies (short axis $>10 \mathrm{~mm}$ ) detected by conventional imaging techniques after COVID-19 vaccinations [5,6,9].

There is a trend towards a higher prevalence of HALNs at 2- $\left[{ }^{18} \mathrm{~F}\right] \mathrm{FDG}$ PET/CT after the second vaccine dose compared to the first dose; this finding can be explained by the boost reactivation after the second vaccine injection [10-13].

Notably, hypermetabolic lymph nodes at $2-\left[{ }^{18} \mathrm{~F}\right] \mathrm{FDG}$ PET/CT after COVID-19 vaccination may also be detected outside the axillary region [10-18].

HALNs are more frequent in immunocompetent than in immunocompromised patients and more frequent in young than in older patients ( $<64$ years), therefore, immune competency and age may play a role in the prevalence of this finding [10-18].

Although the prevalence of HALNs decreases over time after COVID-19 vaccination, HALNs at 2-[ $\left[{ }^{18} \mathrm{~F}\right]$ FDG PET/CT were even observed 10 weeks after COVID-19 vaccination [15]. COVID-19 vaccines seem to be more immunostimulatory as compared to other traditional vaccine agents [1,2], and this may account for their longer-lasting vaccine-related HALNs. However, more studies are needed to clarify the time required after COVID-19 vaccination to allow for resolution of HALNs.

Another frequent finding at 2- $\left[{ }^{18} \mathrm{~F}\right] \mathrm{FDG}$ PET/CT after COVID-19 vaccination is the presence of radiopharmaceutical uptake in the vaccine injection site (deltoid muscle). This finding in cases of concomitant ipsilateral HALNs at 2- $\left[{ }^{18} \mathrm{~F}\right] \mathrm{FDG}$ PET/CT might be useful for determining the vaccine-related nature of HALNs. Whereas HALNs might be a marker of vaccine-induced immune system activation, increasing over time and after the second vaccine dose, the increased metabolic activity in the vaccine injection site is inflammatory in nature, and likely secondary to local trauma [10-18].

Even if the majority of HALNs detected by 2-[18 F]FDG PET/CT after COVID-19 vaccination are related to immune response after vaccine injection, in some patients with oncological diseases, to discriminate HALNs due to COVID-19 vaccination from malignancy, further examinations such as ultrasound and biopsies would be necessary, especially in patients with breast cancer, lymphoma, or melanoma [10-18]. Because there is an overlap in the intensity of $2-\left[{ }^{18} \mathrm{~F}\right] \mathrm{FDG}$ uptake among benign and malignant HALNs, this parameter cannot be used to discriminate these two entities after COVID-19 vaccination; conversely, information about tumor type, disease history, and previous imaging are very useful for assessing the nature of HALNs detected by 2-[ ${ }^{18}$ F]FDG PET/CT after COVID-19 vaccination.

Based on the potential risk of HALNs after COVID-19 vaccine to mimic or mask malignant disease at 2-[ $\left.{ }^{18} \mathrm{~F}\right] \mathrm{FDG}$ PET/CT, patients with cancer with a propensity for spread to ipsilateral axillary lymph nodes (e.g., breast cancer, melanoma, and lymphomas) should have the COVID-19 vaccine in the contralateral arm to the tumor site. Nuclear medicine technologists or anyone collecting anamnestic data should document vaccine site, date, type, and first versus second dose. Overall, recent ipsilateral COVID-19 vaccination history should be recognized as a potential common cause of HALNs on PET/CT scans.

Our systematic review and meta-analysis has several limitations. First, only a limited number of original articles related to the review question were available and all were retrospective monocentric studies with possible selection bias. Histologic proof to exclude malignancy in HALNs detected by $2-\left[{ }^{18}\right.$ F]FDG PET/CT was obtained only in few cases, therefore a verification bias cannot be excluded. The included studies were heterogeneous for characteristics of patients included, type of COVID-19 vaccine, time between COVID-19 vaccination and 2-[18 F]FDG PET/CT, and technical aspects of 2- $\left[{ }^{18} \mathrm{~F}\right] \mathrm{FDG}$ PET/CT. Due to 
limited data, only subgroup analyses taking into account HALNs after first and second dose of COVID-19 vaccine were performed. Other subgroup analyses (i.e., based on the different COVID-19 vaccine or the different time points after vaccination) to statistically explore the heterogeneity could not be performed. On the other hand, a significant publication bias was not observed in our analysis.

Even if described in the literature, we did not consider in our analysis the increased radiopharmaceutical uptake in axillary lymph nodes after COVID-19 vaccination using other PET radiopharmaceuticals beyond 2- $\left.{ }^{18} \mathrm{~F}\right] \mathrm{FDG}[14,16]$, due to their different uptake mechanisms and significance compared to $2-\left[{ }^{18}\right.$ F]FDG. In addition, 2- $\left[{ }^{18} \mathrm{~F}\right]$ FDG PET/CT findings reported in few studies such as splenic or non-axillary lymph nodes $2-\left[{ }^{18} \mathrm{~F}\right] \mathrm{FDG}$ accumulation after COVID 19 vaccination [30] were not investigated in the present metaanalysis due to lack of sufficient data.

We did not focus our systematic review and meta-analysis on CT findings; the reason is that HALNs are frequently normal in size at CT scan [10-18]. However, we would like to underline that it is important that radiologists consider recent COVID-19 vaccination in the differential diagnosis of unilateral axillary lymphadenopathy and are aware of typical appearances of this findings across all imaging methods [31,32].

Larger studies are warranted to confirm the findings reported in this systematic review and meta-analysis. In particular the causal association between HALNs and immunogenicity elicited by COVID-19 vaccination should be further explored. Furthermore, more information about the trend and change of HALNs over time should be obtained. These data could be collected in future studies.

\section{Materials and Methods}

This systematic review conforms to the statement on "Preferred Reporting Items for Systematic Reviews and Meta-Analyses of Diagnostic Test Accuracy studies" (PRISMADTA) and to specific guidelines on systematic reviews and meta-analyses of diagnostic studies [33-35].

\subsection{Search Strategy}

A comprehensive computer literature search of PubMed/MEDLINE, Embase, and Cochrane library databases was performed independently by two authors (GT and MC) in order to identify recently published articles that investigated the prevalence of HALNs detected by $2-\left[{ }^{18} \mathrm{~F}\right] \mathrm{FDG}$ PET/CT after COVID-19 vaccination. A search string was created taking into account the review question. The full search string used is reported in Appendix A. Moreover, further screening of the references of the selected articles was performed to search for additional studies.

The literature search was updated until 28 June 2021.

\subsection{Study Selection}

Original articles reporting data about the prevalence of hypermetabolic lymph nodes detected by $2-\left[{ }^{18}\right.$ F]FDG PET /CT after COVID-19 vaccination were considered eligible for inclusion in this systematic review. The exclusion criteria were as follow: (a) articles outside of the field of interest of this review; (b) case reports and small case series (fewer than 10 cases) related to the review question; and (c) review articles, editorials, comments, letters, and conference proceedings related to the review question. No language or date restrictions were used. Nevertheless, only articles published in the last year were expected to be selected due to the recent availability of COVID-19 vaccines.

The titles and abstracts of the retrieved records were reviewed independently by two researchers (GT and $\mathrm{MC}$ ) according to the inclusion and exclusion criteria previously mentioned. Articles which appeared evidently ineligible were rejected. The full-length versions of the remaining articles were independently reviewed by three researchers (GT, $\mathrm{MC}$, and $\mathrm{BM}$ ) to evaluate their eligibility for inclusion. Any disagreements over articles eligibility were resolved during an online consensus meeting. 


\subsection{Data Extraction}

Two authors performed the data extraction from the eligible studies (GT and BM).

Basic study and patients data were collected for each eligible study including authors' names, publication date, country, study design, type and number of patients recruited, patients' age and sex, type of COVID-19 vaccine injected, and time between vaccine administration and PET/CT scan.

Technical aspects of $2-\left[{ }^{18} \mathrm{~F}\right] \mathrm{FDG}$ PET/CT scans in the included studies were also extracted including data on PET/CT scanner and acquisition, $2-\left[{ }^{18} \mathrm{~F}\right] \mathrm{FDG}$ activity injected, time between 2-[ $\left.{ }^{18} \mathrm{~F}\right] \mathrm{FDG}$ injection and PET/CT image acquisition, and PET/CT image analysis.

Lastly, data on the prevalence of HALNs at 2-[18 F]FDG PET/CT after COVID-19 vaccine administration and data on the $2-\left[{ }^{18} \mathrm{~F}\right] \mathrm{FDG}$ uptake at the vaccine injection site were extracted.

\subsection{Quality Assessment}

The overall quality of the studies included in this systematic review was appraised based on the NIH National Heart, Lung and Blood Institute Study Quality Assessment Tools [36].

\subsection{Statistical Analysis}

For each included study we calculated the prevalence of HALNs at $2-\left[{ }^{18} \mathrm{~F}\right] \mathrm{FDG}$ PET/CT after COVID-19 vaccine as the ratio between the number of patients with HALNs detected by $2-\left[{ }^{18} \mathrm{~F}\right] \mathrm{FDG}$ PET/CT after COVID-19 vaccine and the number of patients undergoing 2- $\left[{ }^{18} \mathrm{~F}\right] \mathrm{FDG}$ PET/CT after COVID-19 vaccine. A similar calculation was performed about the prevalence of $2-\left[{ }^{18} \mathrm{~F}\right] \mathrm{FDG}$ uptake at the vaccine injection site for the same patients. When applicable, subgroup analyses were performed about prevalence of HALNs at 2- $\left[{ }^{18}\right.$ F]FDG PET/CT after first and second dose of COVID-19 vaccine.

Pooled prevalence values were calculated through a meta-analytic approach which considered the weight of each included study. A random-effects model was used for statistical pooling of the data taking into account the heterogeneity between studies. Pooled data were presented with their respective $95 \%$ confidence interval $(95 \% \mathrm{CI})$ values.

Inconsistency index $\left(\mathrm{I}^{2}\right)$ was used to estimate the heterogeneity; this describes the percentage of variation across studies that is due to heterogeneity and not chance [33-35].

The Egger's test was used to assess the publication bias (which occurs when the outcome of a research study influences the publication decision) [33-35].

Statistical analyses were performed using StatsDirect software (Version 3, Birkenhead, UK).

\section{Conclusions}

The prevalence of HALNs detected by 2-[ $\left[{ }^{18} \mathrm{~F}\right] \mathrm{FDG}$ PET/CT after recent COVID-19 vaccination is significant. Physicians must be aware and recognize the possibility of HALNs related to immune response to vaccine injection in the setting of mass vaccination of the population to avoid patient anxiety and unnecessary further examinations or biopsies. Larger studies are needed to confirm the findings of this systematic review and meta-analysis.

Author Contributions: Conceptualization, G.T., B.M., and M.C.; methodology, G.T. and B.M.; software, G.T.; validation, B.M.; formal analysis, G.T. and B.M.; resources, G.T.; data curation, B.M. and M.C.; writing—original draft preparation, G.T. and B.M.; writing—review and editing, M.C., L.G., and L.E. All authors have read and agreed to the published version of the manuscript.

Funding: This research received no external funding.

Institutional Review Board Statement: Not applicable.

Informed Consent Statement: Not applicable.

Data Availability Statement: Data sharing not applicable. 
Conflicts of Interest: The authors declare no conflict of interest.

\section{Appendix A}

Search string used for the literature search: ((COVID) OR (COVID-19) OR (SARS*) OR (coronavirus)) AND (vaccin*) AND ((PET) OR (FDG) OR (fluorodeoxyglucose) OR (positron))

\section{References}

1. Abdulla, Z.A.; Al-Bashir, S.M.; Al-Salih, N.S.; Aldamen, A.A.; Abdulazeez, M.Z. A Summary of the SARS-CoV-2 Vaccines and Technologies Available or under Development. Pathogens 2021, 10, 788. [CrossRef] [PubMed]

2. Sadarangani, M.; Marchant, A.; Kollmann, T.R. Immunological mechanisms of vaccine-induced protection against COVID-19 in humans. Nat. Rev. Immunol. 2021, 21, 475-484. [CrossRef] [PubMed]

3. Katal, S.; Pouraryan, A.; Gholamrezanezhad, A. COVID-19 vaccine is here: Practical considerations for clinical imaging applications. Clin. Imaging 2021, 76, 38-41. [CrossRef] [PubMed]

4. Seban, R.D.; Champion, L.; Yeh, R.; Schwartz, L.H.; Dercle, L. Assessing immune response upon systemic RNA vaccination on [18F]-FDG PET/CT for COVID-19 vaccine and then for immuno-oncology? Eur. J. Nucl. Med. Mol. Imaging 2021, 1-2. [CrossRef]

5. McIntosh, L.J.; Bankier, A.A.; Vijayaraghavan, G.R.; Licho, R.; Rosen, M.P. COVID-19 Vaccination-Related Uptake on FDG PET/CT: An Emerging Dilemma and Suggestions for Management. AJR Am. J. Roentgenol. 2021. [CrossRef]

6. McIntosh, L.J.; Rosen, M.P.; Mittal, K.; Whalen, G.F.; Bathini, V.G.; Ali, T.; Edmiston, K.L.; Walsh, W.V.; Gerber, J.M. Coordination and optimization of FDG PET/CT and COVID-19 vaccination; Lessons learned in the early stages of mass vaccination. Cancer Treat. Rev. 2021, 98, 102220. [CrossRef]

7. Treglia, G. Diagnostic Performance of 18F-FDG PET/CT in Infectious and Inflammatory Diseases according to Published Meta-Analyses. Contrast Media Mol. Imaging 2019, 2019, 3018349. [CrossRef]

8. Tamburello, A.; Treglia, G.; Albano, D.; Bertagna, F.; Giovanella, L. Prevalence and clinical significance of focal incidental 18F-FDG uptake in different organs: An evidence-based summary. Clin. Transl. Imaging 2017, 5, 525-532. [CrossRef]

9. Treglia, G.; Cuzzocrea, M.; Muoio, B.; Elzi, L. PET findings after COVID-19 vaccination: Keep Calm and Carry On. Clin. Transl. Imaging 2021, 9, 209-214. [CrossRef]

10. Adin, M.E.; Isufi, E.; Kulon, M.; Pucar, D. Association of COVID-19 mRNA Vaccine With Ipsilateral Axillary Lymph Node Reactivity on Imaging. JAMA Oncol. 2021, e211794. [CrossRef]

11. Bernstine, H.; Priss, M.; Anati, T.; Turko, O.; Gorenberg, M.; Steinmetz, A.P.; Groshar, D. Axillary Lymph Nodes Hypermetabolism After BNT162b2 mRNA COVID-19 Vaccination in Cancer Patients Undergoing 18F-FDG PET/CT: A Cohort Study. Clin. Nucl. Med. 2021, 46, 396-401. [CrossRef]

12. Cohen, D.; Krauthammer, S.H.; Wolf, I.; Even-Sapir, E. Hypermetabolic lymphadenopathy following administration of BNT162b2 mRNA Covid-19 vaccine: Incidence assessed by [18F]FDG PET-CT and relevance to study interpretation. Eur. J. Nucl. Med. Mol. Imaging 2021, 48, 1854-1863. [CrossRef]

13. Cohen, D.; Hazut Krauthammer, S.; Cohen, Y.C.; Perry, C.; Avivi, I.; Herishanu, Y.; Even-Sapir, E. Correlation between BNT162b2 mRNA Covid-19 vaccine-associated hypermetabolic lymphadenopathy and humoral immunity in patients with hematologic malignancy. Eur. J. Nucl. Med. Mol. Imaging 2021, 1-10. [CrossRef]

14. Eifer, M.; Tau, N.; Alhoubani, Y.; Kanana, N.; Domachevsky, L.; Shams, J.; Keret, N.; Gorfine, M.; Eshet, Y. Covid-19 mRNA Vaccination: Age and Immune Status and its Association with Axillary Lymph Node PET/CT Uptake. J. Nucl. Med. 2021. [CrossRef] [PubMed]

15. Eshet, Y.; Tau, N.; Alhoubani, Y.; Kanana, N.; Domachevsky, L.; Eifer, M. Prevalence of Increased FDG PET/CT Axillary Lymph Node Uptake Beyond 6 Weeks after mRNA COVID-19 Vaccination. Radiology 2021, 210886. [CrossRef] [PubMed]

16. Schroeder, D.G.; Jang, S.; Johnson, D.R.; Takahashi, H.; Navin, P.J.; Broski, S.M.; Thorpe, M.P.; Johnson, G.B.; Young, J.R. Frequency and Characteristics of Nodal and Deltoid FDG and 11C-Choline Uptake on PET Imaging Performed After COVID-19 Vaccination. AJR Am. J. Roentgenol. 2021. [CrossRef] [PubMed]

17. Shin, M.; Hyun, C.Y.; Choi, Y.H.; Choi, J.Y.; Lee, K.H.; Cho, Y.S. COVID-19 Vaccination-Associated Lymphadenopathy on FDG PET/CT: Distinctive Features in Adenovirus-Vectored Vaccine. Clin. Nucl. Med. 2021. [CrossRef] [PubMed]

18. Skawran, S.; Gennari, A.G.; Dittli, M.; Treyer, V.; Muehlematter, U.J.; Maurer, A.; Burger, I.A.; Mader, C.; Messerli, O.; Grünig, H.; et al. [18F]FDG uptake of axillary lymph nodes after COVID-19 vaccination in oncological PET/CT: Frequency, intensity, and potential clinical impact. Eur. Radiol. 2021, 1-9. [CrossRef]

19. Delgado Bolton, R.C.; Calapaquí Terán, A.K.; Erba, P.A.; Giammarile, F. Medical imaging in times of pandemic: Focus on the cornerstones of successful imaging. Eur. J. Nucl. Med. Mol. Imaging 2021, 48, 1724-1725. [CrossRef]

20. Treglia, G. The role of 18F-FDG PET for COVID-19 infection: Myth versus reality. Clin. Transl. Imaging 2020, 1-2. [CrossRef]

21. Annunziata, S.; Delgado Bolton, R.C.; Kamani, C.H.; Prior, J.O.; Albano, D.; Bertagna, F.; Treglia, G. Role of 2-[18F]FDG as a Radiopharmaceutical for PET/CT in Patients with COVID-19: A Systematic Review. Pharmaceuticals 2020, 13, 377. [CrossRef]

22. Burger, I.A.; Husmann, L.; Hany, T.F.; Schmid, D.T.; Schaefer, N.G. Incidence and intensity of F-18 FDG uptake after vaccination with H1N1 vaccine. Clin. Nucl. Med. 2011, 36, 848-853. [CrossRef] [PubMed] 
23. Coates, E.E.; Costner, P.J.; Nason, M.C.; Herrin, D.M.; Conant, S.; Herscovitch, P.; Sarwar, U.N.; Holman, L.; Mitchell, J.; Yamshchikov, G.; et al. Lymph Node Activation by PET/CT Following Vaccination With Licensed Vaccines for Human Papillomaviruses. Clin. Nucl. Med. 2017, 42, 329-334. [CrossRef] [PubMed]

24. Iyengar, S.; Chin, B.; Margolick, J.B.; Sabundayo, B.P.; Schwartz, D.H. Anatomical loci of HIV-associated immune activation and association with viraemia. Lancet 2003, 362, 945-950. [CrossRef]

25. Nakata, J.; Isohashi, K.; Morimoto, S.; Itou, R.; Kamiya, T.; Matsuura, A.; Nakajima, H.; Fujiki, F.; Nishida, S.; Hasii, Y.; et al. Enhanced immune reaction resulting from co-vaccination of WT1 helper peptide assessed on PET-CT. Medicine 2020, 99 , e22417. [CrossRef] [PubMed]

26. Panagiotidis, E.; Exarhos, D.; Housianakou, I.; Bournazos, A.; Datseris, I. FDG uptake in axillary lymph nodes after vaccination against pandemic (H1N1). Eur. Radiol. 2010, 20, 1251-1253. [CrossRef] [PubMed]

27. Shirone, N.; Shinkai, T.; Yamane, T.; Uto, F.; Yoshimura, H.; Tamai, H.; Imai, T.; Inoue, M.; Kitano, S.; Kichikawa, K.; et al. Axillary lymph node accumulation on FDG-PET/CT after influenza vaccination. Ann. Nucl. Med. 2012, 26, 248-252. [CrossRef]

28. Thomassen, A.; Lerberg Nielsen, A.; Gerke, O.; Johansen, A.; Petersen, H. Duration of 18F-FDG avidity in lymph nodes after pandemic H1N1v and seasonal influenza vaccination. Eur. J. Nucl. Med. Mol. Imaging 2011, 38, 894-898. [CrossRef] [PubMed]

29. Win, Z.; Weiner, J.; Listanco, A.; Patel, N.; Sharma, R.; Greenwood, A.; Maertzdorf, J.; Mollenkopf, H.J.; Pizzoferro, K.; Cole, T.; et al. Systematic Evaluation of Kinetics and Distribution of Muscle and Lymph Node Activation Measured by 18F-FDGand 11C-PBR28-PET/CT Imaging, and Whole Blood and Muscle Transcriptomics After Immunization of Healthy Humans with Adjuvanted and Unadjuvanted Vaccines. Front. Immunol. 2021, 11, 613496. [CrossRef]

30. Steinberg, J.; Thomas, A.; Iravani, A. 18F-fluorodeoxyglucose PET/CT findings in a systemic inflammatory response syndrome after COVID-19 vaccine. Lancet 2021, 397, e9. [CrossRef]

31. Brown, A.; Shah, S.; Dluzewski, S.; Musaddaq, B.; Wagner, T.; Szyszko, T.; Wan, S.; Groves, A.; Mokbel, K.; Malhotra, A. Unilateral axillary adenopathy following COVID-19 vaccination: A multimodality pictorial illustration and review of current guidelines. Clin. Radiol. 2021, 76, 553-558. [CrossRef] [PubMed]

32. D'Auria, D.; Fulgione, L.; Romeo, V.; Stanzione, A.; Maurea, S.; Brunetti, A. Ultrasound and shear-wave elastography patterns of COVID-19 mRNA vaccine-related axillary, supra and subclavicular lymphadenopathy. Clin. Transl. Imaging 2021, 1-7. [CrossRef]

33. McInnes, M.D.F.; Moher, D.; Thombs, B.D.; McGrath, T.A.; Bossuyt, P.M.; PRISMA-DTA Group; Clifford, T.; Cohen, J.F.; Deeks, J.J.; Gatsonis, C.; et al. Preferred Reporting Items for a Systematic Review and Meta-analysis of Diagnostic Test Accuracy Studies: The PRISMA-DTA Statement. JAMA 2018, 319, 388-396. [CrossRef] [PubMed]

34. McGrath, T.A.; Alabousi, M.; Skidmore, B.; Korevaar, D.A.; Bossuyt, P.M.M.; Moher, D.; Thombs, B.; McInnes, M.D.F. Recommendations for reporting of systematic reviews and meta-analyses of diagnostic test accuracy: A systematic review. Syst. Rev. 2017, 6, 194. [CrossRef]

35. Sadeghi, R.; Treglia, G. Systematic reviews and meta-analyses of diagnostic studies: A practical guideline. Clin. Transl. Imaging 2017, 5, 83-87. [CrossRef]

36. Study Quality Assessment Tools. Available online: https://www.nhlbi.nih.gov/health-topics/study-quality-assessment-tools (accessed on 30 June 2021). 